\title{
Protophone Development at 4-6 Months and 7-9 Months of Age
}

\author{
Hyunsung Jang ${ }^{a}$, Seunghee $\mathrm{Ha}^{\mathrm{b}}$ \\ ${ }^{a}$ Graduate Program in Speech Language Pathology, Hallym University, Chuncheon, Korea \\ ${ }^{b}$ Division of Speech Pathology and Audiology, Audiology and Speech Pathology Research Institute, Hallym University, Chuncheon, Korea
}

\author{
Correspondence: Seunghee $\mathrm{Ha}, \mathrm{PhD}$ \\ Division of Speech Pathology and Audiology, \\ Audiology and Speech Pathology Research \\ Institute, Hallym University, 1 Hallimdaehak-gil, \\ Chuncheon 24252, Korea \\ Tel: $+82-33-248-2215$ \\ Fax: +82-33-256-3420 \\ E-mail: shha@hallym.ac.kr
}

Received: July 5, 2019

Revised: August 14, 2019

Accepted: August 14, 2019

This research has been supported by the National Research Foundation of Korea (NRF) grant funded by the Korean Government (No. NRF2016S1A2911363).

\begin{abstract}
Objectives: The onset of canonical babbling is an important developmental precursor to spoken language. This study aimed to examine developmental patterns of protophones at 4-6 months and 7-9 months of age and test whether frequent protophones with formant transition at 4-6 months would predict the onset of canonical babbling at 7-9 months. Methods: Vocalization samples using Language ENvironment Analysis (LENA) were obtained from 15 typically developing infants at 4-6 months and 7-9 months of age. Coders analyzed 20 five-minute segments with the highest child vocalization rate and determined the protophone type of each utterance. This study compared each protophone type at 4-6 months and 7-9 months. Infants were divided into the two groups who did or did not reach the canonical babbling stage. The study examined whether the two groups showed differences in the frequency of protophones with formant transition at 4-6 months and whether protophones with formant transition at 4-6 months have a close relationship with canonical babbling at 7-9 months. Results: The results showed that canonical babbling increased significantly at 7-9 months compared to 4-6 months. The results indicated that infants who do and do not reach the canonical babbling stage at 7-9 months did not show any significant differences in the frequency of protophones with formant transition at 4-6 months, which had no significant relationship with canonical babbling at 7-9 months. Conclusion: This study showed developmental patterns of protophones and suggests that most infants appear to begin canonical babbling suddenly rather than show gradual increases.
\end{abstract}

Keywords: Canonical babbling, Protophones, Formant transition, Korean-acquiring children
영아들은 첫 단어를 산출하기 전까지 다양한 발성을 통해 신체 적 욕구나 의사소통 의도를 표현하고 자신의 음성을 탐색하기 시 작한다. 여러 연구자들은 영아가 태어나면서부터 첫 단어를 산출하 기까지 영아가 산출하는 다양한 발성을 하위 유형별로 조작적으로 정의하고 각 발성 단계를 지정하였다(Nathani, Ertmer, \& Stark, 2006; Oller, 2000). 영아들은 준모음(완전히 공명되지 않은 모음 같 은 소리)을 산출하는 것부터 시작하여 모음(완전히 공명된 모음), 활음, 경계선 옹알이(marginal babbling, $\mathrm{MB}$ )를 거쳐 음절성 옹알 이(canonical babbling, $\mathrm{CB}$ )를 산출한다. 음절성 옹알이를 산출하 는 단계에 접어든 아동은 복잡한 음절, 자곤 등 조금 더 진전된 음
절성 옹알이를 산출하면서 생후 12 개월 정도에 첫 단어를 산출한 다(Nathani et al., 2006). Oller (2000)는 이러한 초기 발성을 신체의 불편함과 욕구, 감정 상태 등 한 가지 메시지만을 전달하는 생리적 발성과 구별해서 말과 같은 발성(speech-like vocalizations) 또는 원 시발성(protophones)으로 지칭하고 이후 발달하는 말에 중요한 기 초가 된다고 하였다. 영아들이 산출하는 원시발성 중 특별히 음절 성 옹알이는 이후 발달하는 낱말의 기본 구성요소를 이루기 때문 에 말 발달에 있어서 중요한 이정표에 해당한다. Lynch, Oller, Steffens와 Levine (1995)은 아동이 산출한 기본음절(canonical syllable)을 총음절로 나눈 음절성 옹알이 비율(canonical babbling ra- 
tio, CBR)이 0.15 이상이면 음절성 옹알이 단계(canonical babbling stage)에 진입한 것으로 정의하였다. 일반아동과 선천적 장애를 동 반한 아동(다운증후군, 구개열, 청각장애 등)을 대상으로 음절성 옹알이 산출을 비교한 연구는, 선천적 장애를 동반한 아동이 음절 성 옹알이의 시작이 지연되고 음절성 옹알이 패턴에서 차이가 있 음을 보여주었다(Chapman, Hardin-Jones, Schulte, \& Halter, 2001; Lynch et al., 1995; Oller \& Eilers, 1988).

영아는 음절성 옹알이 단계에 진입하면서 조음기관을 사용하여 자음과 모음을 적절하게 결합할 수 있게 된다. 이때, 적절하게 결합 한다는 것은 자음요소와 모음요소가 적절한 타이밍으로 결합하여 산출한다는 것을 말한다. 이전 연구에서는 자음요소와 모음요소 사이 포먼트 전이가 $120 \mathrm{~ms}$ 이하일 때 적절한 타이밍으로 자음요 소와 모음요소가 결합되어진 것으로 보고, 이러한 음절을 음절성 옹알이로 정의하였다(Lee, Jhang, Relyea, Chen, \& Oller, 2018). 포 먼트 전이가 나타난다는 것은 아동이 발성하는 동안 조음기관을 움직인다는 것을 의미한다. 따라서 영아가 음절성 옹알이를 산출 한다는 것은 혀, 턱, 입술 등의 조음기관이 적절한 운동력과 협응력 을 가지게 되어 첫 단어를 산출하기 전에 준비하는 단계라고 볼 수 있다. 영아들은 음절성 옹알이를 산출하기 전 조음기관의 적절한 운동력과 협응력을 가지기 위해 자신의 조음기관을 탐색하고 다양 한 발성을 산출하면서 말 산출에 대한 연습을 한다. 이전 연구에 따 르면 음절성 옹알이를 산출하기 바로 직전의 단계를 확장단계(4-6 개월)라고 명명하였다(Nathani et al., 2006). 확장단계에는 모음, 2 회 이상 모음의 연속체, 활음, 흡기음, 높은 음도 소리(squeal), 경계 선 옹알이가 포함되어 있다. 이러한 원시발성 중 활음과 경계선 옹 알이는 포먼트 전이가 나타나는 발성유형이다. 또한 2회 이상 연속 해서 모음을 산출하는 발성유형 중 동일한 모음의 반복이 아닌 서 로 다른 모음이 연속해서 산출될 경우는 포먼트 전이가 나타나는 발성유형이다. 즉 활음, 서로 다른 일련의 모음, 경계선 옹알이는 영 아가 발성하는 동안 느리더라도 자신의 조음기관을 움직이는 연습 을 하고 있다고 볼 수 있다. 적절한 타이밍이 아니더라도 발성하는 동안 조음기관을 조금씩 움직이면서 산출되는 활음, 서로 다른 일 련의 모음 그리고 경계선 옹알이는 조음기관의 적절한 운동력과 협 응력을 향상시켜 음절성 옹알이 발달에 도움이 될 수 있다.

음절성 옹알이 산출의 시작 및 발달은 이후 말 발달 과정에서 중 요한 이정표이기 때문에 음절성 옹알이의 시작 및 발달패턴과 관련 하여 여러 연구들이 진행되어 왔다. 논리적으로는 음절성 옹알이 를 산출하기 전 원시발성, 특히 포먼트 전이가 나타나는 활음, 경계 선 옹알이의 산출이 증가하고, 이러한 유형의 원시발성의 빈도가 음절성 옹알이의 출현에 영향을 끼칠 것으로 가설해 볼 수 있다. 왜
냐하면 포먼트 전이가 나타난다는 것은 발성을 하는 도중 조음기 관을 움직인다는 것을 말하며, 조음기관을 많이 사용하고 움직이 는 연습을 많이 하는 것은 음절성 옹알이 발달에 도움이 될 수 있 기 때문이다. 음절성 옹알이가 본격적으로 산출되기 전에 다른 특 정 원시발성 유형의 빈도가 높아, 음절성 옹알이의 시작과 밀접한 관련이 있는지, 아니면 그러한 선행 원시발성의 빈도와 무관하게 음절성 옹알이가 출현하고 빈도가 증가하는지 살펴볼 필요가 있 다. 일반적으로 현재는 음절성 옹알이의 시작 시기, 빈도, 구조 및 형태 등으로 이후 말-언어문제를 예측한다. 만약 음절성 옹알이의 시작을 보다 더 일찍 예측할 수 있는 요인을 파악한다면 말-언어장 애를 보다 더 일찍 확인하고 음절성 옹알이 산출을 보다 더 적극적 으로 촉진하는 것을 권고할 수 있겠다. 따라서 본 연구는 음절성 옹 알이가 산출되기 전인 4-6개월과 음절성 옹알이 단계에 진입하는 아동들이 관찰되기 시작하는 7-9개월의 발성 자료를 종단 수집하 여 발성유형별 변화를 살펴보고, 7-9개월의 음절성 옹알이와 4-6개 월의 원시발성과 관계가 있는지 살펴보고자 한다. 특히 포먼트 전 이를 동반한 원시발성의 빈도가 음절성 옹알이 출현과 직접적으로 관련이 있을 것이라는 가설하에 4-6개월의 원시발성을 포먼트 전 이를 동반한 발성과 동반하지 않는 발성으로 나누어서 7-9개월의 음절성 옹알이 산출과의 관계를 살펴보았다.

\section{연구방법}

\section{대상자}

본 연구의 대상자는 한국어권 영아의 옹알이 패턴을 연구하고 있는 종단 연구에서 모집된 15명으로 4-6개월과 7-9개월에 수집된 발성 자료를 사용하였다. 수집된 15 명의 일반영아는 부모면담 시 출산 전후 특이사항이 없었으며, 신생아 청력검사 시 아동의 청력 수준이 정상 범주에 속하였다. 수집된 15명의 영아 중 남아는 9명 여아는 6명이었다. 4-6개월 자료의 평균월령은 5.40 개월 $(\mathrm{SD}=0.74)$ 에 해당하였고, 7-9개월 자료의 평균월령은 8.40 개월 $(\mathrm{SD}=0.74)$ 에 해당하였다.

\section{자료수집}

자료수집은 한림대학교 생명윤리위원회의 승인을 받아 진행되 었다(No. HIRB-2016-078-3-CCR). 언어병리학전공 대학원생이 각 대상자의 가정에 방문하여 먼저 아동의 신체적 발달과 관련하여 아동의 부모와 인터뷰를 진행하고 검사자와 부모가 각각 20 분간 아동과 자유롭게 상호작용을 하였다. 상호작용하는 동안 소형 녹 음기인 LENA system (Language ENvironment Analysis system)과 
비디오 녹화를 동시에 진행하여 아동의 발화를 수집하였으며, 추 가적으로 연구자는 부모에게 녹음기를 아동이 하루 동안 착용하 게 하여 검사자가 없는 자연스러운 일상생활에서의 하루를 녹음하 도록 요청하였다.

\section{자료분석}

분석 절차로 먼저, LENA 녹음기를 이용하여 하루 종일 녹음된 자료를 5 분 간격으로 구간을 나누어 한 영아당 가장 많이 발성한 20 개의 구간을 선택하였다. 선택한 구간은 분석자의 편향을 방지하 기 위해 영아의 이름, 월령을 알 수 없도록 정보를 제거하였다. 자료 분석은 Action Analysis Coding and Training Software (AACT; Delgado, Buder, \& Oller, 2010) 프로그램을 사용하여 청지각적 판 단에 의해 기본적으로 이루어졌다. AACT는 분석 중인 음성자료 의 파형과 스펙트로그램을 실시간으로 관찰할 수 있기 때문에 청 지각적 판단이 모호한 경우 보완적으로 파형과 스펙트로그램에 나 타난 음향학적 특성을 참고하였다(Ha \& Oller, 2019). 약 1년간 초 기 발성에 대한 집중적인 듣기 훈련 및 분석을 마친 언어병리학전 공 대학원생인 제1저자가 모든 자료를 분석하였다. 호흡 단위(breath group)에 따라 나눈 발화(utterance)를 기준으로 발성유형을 분류 하였다. 발화의 앞 혹은 뒤에 숨을 쉬는 소리가 들리지 않고 $200 \mathrm{~ms}$ 이상의 묵음이 지속되면 발화를 분리하여 별개의 발화로 간주하 였다. 호흡 단위로 나눈 발화에 두 개 이상의 서로 다른 유형의 발성 이 포함될 수 있는데 발달면에서 가장 진전된 발성유형으로 해당 발화를 코딩하였다. 또한 녹음된 세션에서 웃음, 울음, 생리적 소리 (트림, 딸꾹질 등)와 소음이 동반되어 아동의 발화를 정확히 들을 수 없는 경우는 코딩에서 제외하였다.

\section{분석치}

아동의 각 발화는 준모음, 모음, 포먼트 전이가 없는 연속 모음체, 포먼트 전이를 동반한 연속 모음체, 경계선 옹알이, 음절성 옹알이 로 분류되었다. 각각의 척도는 Nathani 등(2006)에 의해 개발된 SAEVD-R (The Stark Assessment of Early Vocal DevelopmentRevised)의 조작적 정의를 참고하여 아래의 기준으로 정하였다.

1) 준모음(quasi vowel, QV): 반공명핵(quasi-resonant nuclei, Q) 과 완전공명핵(fully-resonant nuclei, F)을 포함한다. 반공명핵 은 영아가 소리를 산출할 때 성대 진동이 완전히 일어나지 않 은 채 산출되며, 일반적으로 소리의 지속시간이 짧고, 비음화 가 나타난다. 완전공명핵은 반공명핵보다 소리의 지속시간이 길고, 성대 진동과 공명이 보다 완전히 일어나지만 성인 모음 으로 전사될 수 없는 소리이다.
2) 모음(vowel, V): 성대 진동과 공명이 완전히 일어나는 소리이 고, 성인 모음으로 전사될 수 있는 단일 모음이다.

3) 포먼트 전이가 없는 연속 모음체(series of vowel without formant transition, SV): 형태가 같은 모음이 반복되면서 산출될 때를 말하며, 모음 산출 사이 영아가 숨을 쉬지 않고 연속적으 로 같은 모음을 산출할 때를 포함한다(예: / 아아/).

4) 포먼트 전이를 동반한 연속 모음체(series of vowel with formant transition, SVFT): 공명 주파수 전이가 나타나는 모음으 로, 활음(vowel glide)과 형태가 바뀌는 일련의 모음이 포함된 다. 이때 활음은 모음 앞에 반모음이 동반되어 공명주파수 변 화가 있는 모음류를 말하며 각 분절 사이 막힘이 없는 소리를 말한다. 활음은 공명주파수 전이가 $200 \mathrm{~ms}$ 이상으로 청자가 음질의 변화를 지각할 수 있다. 형태가 바뀌는 모음은 한 발화 내 2 개 이상의 형태가 다른 모음류를 산출하는 것을 말하며, 모음 산출 사이 영아가 숨을 쉬지 않고 연속적으로 다른 모음 을 산출할 때를 포함한다(예: /아우/).

5) 경계선 옹알이(MB): 자음처럼 들리는 소리와 모음처럼 들리 는 소리가 결합될 때 자음요소와 모음요소 사이 공명주파수 전이가 지각될 정도로 느리거나 자음처럼 들리는 소리만 산출 되는 것을 말한다.

6) 음절성 옹알이(CB): 자음처럼 들리는 소리와 완전히 공명된 모음이 적절히 결합될 때를 말하며, 결합될 때 자음요소와 모 음 사이 공명주파수 전이가 청자가 지각을 할 수 없을 정도이 며 공명주파수 전이가 $120 \mathrm{~ms}$ 미만으로 빠르다(예: [바], [다]). 제시된 분석치들은 발성하는 동안 포먼트 전이를 동반하는가 하 지 않는가에 따라 구분될 수 있다. 준모음, 모음, 포먼트 전이 없는 연속 모음체는 발성하는 동안 포먼트 전이를 동반하지 않는다. 포 먼트 전이 동반 연속 모음체, 경계선 옹알이, 음절성 옹알이는 발성 하는 동안 포먼트 전이를 동반하게 된다.

\section{통계분석}

통계처리는 SPSS version 25.0 프로그램을 사용하였다. 4-6개월 때와 7-9개월 때의 발성유형별 변화를 살펴보기 위해, 대응표본 $t$ 검정을 사용하였다. 또한, 7-9개월 때의 음절성 옹알이와 4-6개월 때의 원시발성 간 관계를 살펴보고자, 두 가지 방법으로 분석하였 다. 먼저 음절성 옹알이에 진입한 아동과 진입하지 못한 아동을 구 분하여 4-6개월 때의 발성유형을 비교하고자 독립표본 $t$-검정을 사 용하였다. 또한 7-9개월에 산출된 음절성 옹알이와 4-6개월 발성 간 상관관계를 확인하기 위해 상관분석으로 Pearson 적률상관계 수를 사용하였다. 유의수준은 $p<.05$ 로 정하였다. 


\section{연구결과}

\section{발성형태별 산출빈도}

영아가 4-6개월 때와 7-9개월 때 산출한 총발화수와 발성형태별 평균빈도 및 산출률을 Table 1에 제시하였고 발성형태별 평균빈도 에 따른 그래프를 Figure 1에 제시하였다. 총발화수는 4-6개월에 평균 352.53개, 7-9개월에 평균 411.60개로 나타났다. 아동은 두 월 령 시기에 모두 준모음이 각각 평균 179.67 개, 158.60 개로 산출빈도 가 가장 높았다. 4-6개월에서 음절성 옹알이가 평균 7.93개로 산출 빈도가 가장 낮았으며, 7-9개월에서는 포먼트 전이 없는 연속 모음 체가 평균 8.13 개로 산출빈도가 가장 낮았다. 월령이 증가하면서 준 모음 산출이 감소하고 모음과 음절성 옹알이 산출이 증가하는 경 향이 나타났다(Figure 1).

월령에 따라 발성유형별 산출에 차이가 있는지 확인하기 위해 대응표본 $t$-검정을 실시한 결과, 음절성 옹알이 산출에서만 유의미 한 차이가 나타났다 $(t=-3.181, p=.007)$. 월령에 따라 포먼트 전이 를 동반한 발성 산출과 동반하지 않는 발성 산출에 차이가 있는지 확인하기 위해서 대응표본 $t$-검정을 실시한 결과, 포먼트 전이를 동 반하지 않는 발성의 산출은 유의미한 차이가 나타나지 않았다 $(t=$ $-.319, p=.755)$. 포먼트 전이를 동반한 발성의 산출은 월령이 증가하 면서 유의미하게 증가하는 결과가 나타났다 $(t=-2.491, p=.026)$.

\section{7-9개월 음절성 옹알이와 4-6개월 발성 간의 관계}

영아가 7-9개월 때의 음절성 옹알이 비율과 4-6개월 때의 발성유 형별 빈도를 Table 2에 제시하였다. 포먼트 전이를 동반한 원시발성 의 빈도가 음절성 옹알이 출현과 직접적으로 관련이 있을 것이라
는 가설을 검증하기 위해, 7-9개월 때 음절성 옹알이 단계에 진입한 아동과 진입하지 못한 아동을 구분하였다. 음절성 옹알이 비율에 관한 선행연구(Lynch et al., 1995)에서 음절성 옹알이 단계에 진입 한 기준이 되는 음절성 옹알이 비율 0.15를 토대로 7-9개월에 영아 15 명 중 6 명이 음절성 옹알이 단계에 진입하였다. 음절성 옹알이 단 계에 진입한 6명은 4-6개월에서 총 평균 290개의 발화를 산출했다. 산출한 발화 중 포먼트 전이를 동반한 발성은 평균 49.50 개, 포먼트 전이를 동반하지 않는 발성은 평균 240.50 개를 산출했다. 음절성 옹알이 단계에 진입하지 못한 9명은 4-6개월에서 총 평균 394.22개 의 발화를 산출했다. 산출한 발화 중 포먼트 전이를 동반한 발성은 평균 46.44개, 포먼트 전이를 동반하지 않는 발성은 평균 347.78 개 를 산출했다. 음절성 옹알이 단계에 진입하지 못한 9 명의 아동들은 음절성 옹알이 단계에 진입한 6 명의 아동들에 비해 상대적으로 포

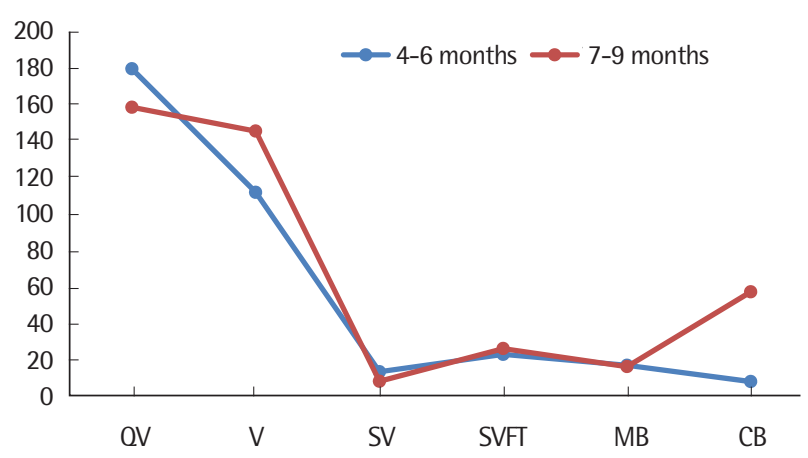

Figure 1. Total mean frequency by utterance types.

$\mathrm{QV}=$ quasi vowel; $\mathrm{V}=$ vowel; $\mathrm{SV}=$ series of vowels without formant transition; SVFT= series of vowels with formant transition; $\mathrm{MB}=$ marginal babbling; $\mathrm{CB}=$ canonical babbling.

Table 1. Total frequency and mean ratio by utterance types

\begin{tabular}{|c|c|c|c|c|c|}
\hline & & & & & \\
\hline & Frequency & Ratio & Frequency & Ratio & $l$ \\
\hline OV & $179.67(99.56)$ & $0.500(0.152)$ & $158.60(67.77)$ & $0.386(0.138)$ & 1.006 \\
\hline V & $111.87(53.58)$ & $0.325(0.113)$ & $145.47(59.62)$ & $0.353(0.102)$ & -2.004 \\
\hline SV & $13.33(14.22)$ & $0.037(0.036)$ & $8.13(8.14)$ & $0.019(0.016)$ & 1.131 \\
\hline WOFT & $304.87(127.04)$ & $0.862(0.080)$ & $312.20(103.24)$ & $0.758(0.160)$ & -.319 \\
\hline SVFT & $22.87(16.44)$ & $0.066(0.038)$ & $26.07(14.91)$ & $0.063(0.034)$ & -.677 \\
\hline $\mathrm{MB}$ & $16.87(17.30)$ & $0.046(0.041)$ & $16.13(15.92)$ & $0.038(0.033)$ & .160 \\
\hline CB & $7.93(8.76)$ & $0.026(0.034)$ & $57.20(62.47)$ & $0.140(0.143)$ & $-3.181^{*}$ \\
\hline WFT & $47.67(30.47)$ & $0.138(0.080)$ & $99.40(72.81)$ & $0.242(0.160)$ & $-2.491^{*}$ \\
\hline Number of utterance & $352.53(133.51)$ & - & $411.60(105.40)$ & - & -1.345 \\
\hline
\end{tabular}

Values are presented as mean (SD).

$\mathrm{QV}=$ quasi vowel; $\mathrm{V}=$ vowel; $\mathrm{SV}=$ series of vowels without formant transition; $\mathrm{WOFT}=$ protophones without formant transition $(\mathrm{OV}+\mathrm{V}+\mathrm{SV})$; $S \mathrm{~V} F \mathrm{~T}=\mathrm{series}$ of vowels with formant transition; $\mathrm{MB}=$ marginal babbling; $\mathrm{CB}=$ canonical babbling; $\mathrm{WFT}=$ protophones with formant transition (SVFT+MB+CB).

${ }^{*} p<.05$. 
Table 2. CBR in 7-9 months and frequency of utterance types in 4-6 months

\begin{tabular}{|c|c|c|c|c|c|c|c|c|c|c|}
\hline \multirow{2}{*}{ Child no. } & \multicolumn{9}{|c|}{ 4-6 months } & \multirow{2}{*}{$\frac{7-9 \text { months }}{\text { CBR }}$} \\
\hline & OV & V & SV & WOFT & SVFT & $\mathrm{MB}$ & $\mathrm{CB}$ & WFT & Total & \\
\hline 1 & 360 & 91 & 7 & 458 & 17 & 21 & 6 & 44 & 502 & .032 \\
\hline 2 & 162 & 218 & 33 & 413 & 68 & 14 & 4 & 86 & 499 & .041 \\
\hline 3 & 110 & 104 & 24 & 238 & 18 & 12 & 7 & 37 & 275 & .100 \\
\hline 4 & 408 & 205 & 5 & 618 & 19 & 9 & 4 & 32 & 650 & .028 \\
\hline 5 & 188 & 108 & 23 & 319 & 42 & 25 & 4 & 71 & 390 & .083 \\
\hline 6 & 59 & 134 & 10 & 203 & 18 & 3 & 0 & 21 & 224 & .064 \\
\hline 7 & 147 & 82 & 5 & 234 & 37 & 24 & 27 & 88 & 322 & .033 \\
\hline 8 & 151 & 177 & 49 & 377 & 12 & 9 & 1 & 22 & 399 & .080 \\
\hline 9 & 207 & 63 & 0 & 270 & 9 & 5 & 3 & 17 & 287 & .055 \\
\hline 10 & 150 & 153 & 23 & 326 & 24 & 71 & 14 & 109 & 435 & $.194^{\mathrm{a}}$ \\
\hline 11 & 178 & 68 & 1 & 247 & 32 & 31 & 7 & 70 & 317 & $.184^{\mathrm{a}}$ \\
\hline 12 & 278 & 81 & 11 & 370 & 9 & 13 & 6 & 28 & 398 & $.156^{a}$ \\
\hline 13 & 77 & 59 & 7 & 143 & 4 & 3 & 4 & 11 & 154 & $.426^{a}$ \\
\hline 14 & 131 & 53 & 1 & 185 & 11 & 9 & 3 & 23 & 208 & $.351^{a}$ \\
\hline 15 & 207 & 63 & 0 & 172 & 9 & 5 & 3 & 56 & 228 & $.376^{a}$ \\
\hline
\end{tabular}

$\mathrm{CBR}=$ canonical babbling ratio; $\mathrm{QV}=$ quasi vowel; $\mathrm{V}=$ vowel; $\mathrm{SV}=$ series of vowels without formant transition; WOFT= protophones without formant transition (QV+V+SV); $\mathrm{SVFT}=$ series of vowels with formant transition; $\mathrm{MB}=$ marginal babbling; $\mathrm{CB}=$ canonical babbling; WFT = protophones with formant transition (SVFT+MB+CB). ${ }^{a} A$ child who achieved the CB stage.

Table 3. Percentage (\%) of utterance types by each group

\begin{tabular}{lccc}
\hline & $\begin{array}{c}\text { Children who did not } \\
\text { reach CB stage }\end{array}$ & $\begin{array}{c}\text { Children who reach } \\
\text { CB stage }\end{array}$ & $t$ \\
\hline WOFT & $347.78(133.75)$ & $240.50(91.00)$ & 1.709 \\
WFT & $46.44(28.09)$ & $49.50(36.47)$ & -.184 \\
\hline
\end{tabular}

Values are presented as mean (SD).

$\mathrm{CB}=$ canonical babbling; WOFT = protophones without formant transition (quasi vowel+vowel+series of vowels without formant transition); WFT= protophones with formant transition (series of vowels with formant transition+marginal babbling+CB).

먼트 전이를 동반하지 않는 발성을 더 많이 산출하고, 포먼트 전이 를 동반하는 발성은 더 적게 산출하는 경향이 나타났다. 하지만 음 절성 옹알이에 진입한 아동과 진입하지 못한 아동의 4-6개월 때 포 먼트 전이를 동반한 발성과 동반하지 않은 발성 빈도의 차이를 살 펴 본 결과, 통계적으로는 유의하지 않았다(Table 3).

음절성 옹알이와 4-6개월 때의 발성에서 총 발화 수 및 포먼트 전 이 동반 유무가 상관관계를 가지는지 Pearson 상관분석을 실시하 였다. 상관계수를 살펴본 결과, 7-9개월 음절성 옹알이의 빈도와 총 발화수와는 $r=-.509$ ( $p=.053)$, 포먼트 전이를 동반한 발성과는 $r=-.155(p=.581)$, 포먼트 전이를 동반하지 않는 발성과는 $r=-.497$ ( $p=.059)$ 로 음절성 옹알이 빈도와 총발화수, 포먼트 전이 동반 유 무는 유의미한 상관관계가 나타나지 않았다.

\section{논의 및 결론}

영아가 의미 있는 말을 산출하기 위해서는 자음과 모음을 빠른 포먼트 전이로 결합하여 성숙한 음절을 산출할 수 있는 능력이 선 행적으로 발달되어야 하기 때문에 음절성 옹알이의 시작은 이후 말-언어발달에 있어서 중요한 이정표이다(Lewedag, 1995). 전형적 으로 발달하는 일반아동의 경우 음절성 옹알이를 보통 5-6개월에 산출하기 시작하며, 늦어도 10 개월 이전까지는 산출한다(Lee et al., 2018; Lynch et al., 1995; Oller, Eilers, Steffens, Lynch, \& Urbano, 1994). 생후 1 년 동안 산출되는 다양한 원시발성은 불완전한 공명 음에서부터 서로 다른 음절이 결합된 변형적 옹알이까지 일련의 출 현순서를 보이면서 점진적으로 발달해 나간다. 음절성 옹알이가 본 격적으로 산출되기 전에 조음기관의 움직임을 반영하는 포먼트 전 이가 나타나는 활음, 서로 다른 모음의 연속체, 경계선급 옹알이와 같은 원시발성의 활발한 산출은 음절성 옹알이 출현의 전조가 될 수 있다. 본 연구는 음절성 옹알이의 출현을 예측할 수 있는 전조가 생후 4-6개월에 산출하는 원시발성의 유형과 빈도에 나타나는지 살펴보고자 하였다. 먼저 음절성 옹알이가 출현하기 전과 후에 해 당하는 생후 4-6개월과 7-9개월의 종단 발성 자료를 바탕으로 발성 유형별 변화를 살펴보고, 7-9개월의 음절성 옹알이와 4-6개월의 원 시발성과 관계가 있는지 살펴보았다.

생후 4-6개월과 7-9개월의 발성유형별 산출빈도를 비교한 결과, 
음절성 옹알이만이 유의미하게 증가하였다. 발성을 크게 포먼트 전 이를 동반한 원시발성과 동반하지 않은 원시발성으로 분류하여 살 펴보았을 때도 포먼트 전이를 동반하지 않은 원시발성은 4-6개월 과 7-9개월 간의 유의미한 차이를 보이지 않았다. 포먼트 전이를 동 반한 원시발성은 음절성 옹알이의 유의미한 증가로 인해 4-6개월 과 7-9개월 간의 유의미한 차이를 보였다. 이러한 결과는 생후 4 개 월부터 9 개월 사이에 아동의 말 발달에 있어서 가장 견고하게 일어 나는 큰 변화는 음절성 옹알이의 증가임을 다시 한번 확인시켜주 고 있다. 동시에 원시발성이 일련의 출현순서를 보이면서 점진적으 로 발달해 나가지만 각각의 원시발성이 특정 기간에만 산출되는 것 이 아니고 보다 진전된 형태가 출현하더라도 상당 기간 동안 지속 적으로, 여러 형태와 동시에 산출되는 모습을 보여주고 있다. 음절 성 옹알이가 7-9개월에 본격적으로 산출되었지만 준모음과 모음의 산출빈도는 두 시기에 모두 가장 높았다. 이러한 결과는 SAEVD-R (Nathani et al., 2006)을 사용하여 생후 5-20개월 한국 아동 58명의 초기 발성 발달 과정을 횡단적으로 살펴본 $\mathrm{Ha}$, Seol과 Pae (2014)의 연구결과와 일치하였다. 선행연구에서는 모음이 관찰 기간 동안 내 내 가장 우세한 발성유형 중 하나로 산출되었다. 마찬가지로 영어 권 아동을 대상으로 Nathani 등(2006)에서도 모음이 16-20개월까 지 우세하게 산출된다고보고하였다.

한편 영아가 7-9개월 때 산출한 음절성 옹알이와 4-6개월 때 산 출한 원시발성이 관계가 있는지도 살펴보았다. 특히 4-6개월에 음 절성 옹알이의 전조가 될 수 있는 포먼트 전이를 동반한 원시발성 의 빈도가 높을수록 아동이 7-9개월에 음절성 옹알이 단계에 안정 적으로 진입할 것으로 가정하고 이를 검증하고자 하였다. 먼저 선 행연구(Lynch et al., 1995)에서 제시한 0.15 이상의 음절성 옹알이 비율을 기준으로 음절성 옹알이 단계에 진입한 아동과 진입하지 못한 아동을 구분하였다. 그 다음, 4-6개월에 산출한 포먼트 전이 를 동반하는 발성과 동반하지 않는 발성의 빈도 차이가 나타나는 지 확인하였다. 음절성 옹알이 단계에 진입한 아동 6 명과 진입하지 못한 아동 9명이 4-6개월에 산출한 원시발성을 비교해 본 결과, 포 먼트 전이를 동반한 발성빈도와 동반하지 않는 발성빈도에 유의미 한 차이가 나타나지 않았다. 또한 7-9개월에서의 음절성 옹알이 빈 도와 4-6개월에 산출된 포먼트 전이 동반 유무에 따른 원시발성의 빈도 간의 상관관계도 유의미하지 않았다. 따라서 포먼트 전이를 동반한 원시발성이 음절성 옹알이보다 먼저 산출되기는 하지만, 포 먼트 전이를 동반한 원시발성의 빈도와는 독립적으로 음절성 옹알 이가 출현하고 증가한다고 결론지을 수 있다. 이러한 점은 대부분 의 영아가 음절성 옹알이를 시작하기 전에 유사한 형태의 원시발성 을 활발히 발성하면서 전조를 보이고 서서히 음절성 옹알이가 증가
되기 보다는 갑작스럽게 산출하기 시작하는 경향이 강하다는 관찰 보고(Oller, 2000)를 지지하는 결론이라 할 수 있다. 또한 4-16개월 의 발성 자료를 바탕으로 2 개월 간격으로 음절성 옹알이 비율의 변 화를 살펴본 Oller 등(1994)의 연구에서도 이러한 급격한 음절성 옹알이의 증가 패턴이 보고된다. Oller 등(1994)은 음절성 옹알이 비율이 4 개월에는 $0.04,6$ 개월에는 $0.12,8$ 개월에는 0.27 로 큰 폭으 로 증가하다가 서서히 작은 폭으로 증가해 16 개월에는 0.42 가 된다 고 보고하면서 음절성 옹알이가 6-8개월에 급격하게 산출되기 시 작한다고 논하였다.

본 연구는 3개월 간격으로 수집된 자료를 바탕으로 음절성 옹알 이 단계 전과 후의 다양한 원시발성의 변화를 살펴보았다. 생후 4-9 개월 간의 원시발성의 산출 변화를 통해 포먼트 전이를 동반하는 활음이나 경계선급 옹알이와 같은 원시발성 형태가 음절성 옹알이 보다 먼저 산출되기 시작하고 이러한 산출 경험이 음절성 옹알이 산출의 기초가 될 수 있음을 확인하였다. 또한 음절성 옹알이의 시 작을 미리 예측할 수 있는 요인을 찾고자 포먼트 전이를 동반한 원 시발성의 빈도에 초점을 맞추어 살펴보았다. 하지만 4-6개월의 포 먼트 전이를 동반한 원시발성의 빈도를 토대로 생후 7-9개월에 음 절성 옹알이를 안정적으로 산출하는 아동과 아직 음절성 옹알이 단계에 진입하지 못한 아동을 구분할 수는 없었다. 이러한 결과는 적은 연구대상자의 수와 3 개월의 간격으로 수집된 종단 자료의 실 험 설계상의 본질적인 제한점과 관련이 있을 수 있다. 본 연구에서 수집된 15 명의 대상자를 바탕으로 음절성 옹알이와 전이구간이 포 함되는 원시발성 간의 상관관계를 살펴보기에는 다소 제한점이 있 다. 이러한 문제를 해결하기 위해 추후 더 많은 아동들을 대상으로 연구를 진행하여 음절성 옹알이와 전이구간이 포함되는 원시발성 간의 관계를 살펴보는 것이 필요하다. 또한 아동은 전체적인 발달 이 빠르게 이루어지고 동시에 발달 속도와 특성에 있어서 개인차가 큰 시기이다. 따라서 종단 자료수집 간격을 줄여 영아의 발성 발달 을 조금 더 세밀하게 관찰할 필요가 있다. 더 나아가 원시발성의 전 체적인 발달 과정을 포괄적으로 살펴보고 영유아 의사소통 평가에 활용되기 위해서는 음절성 옹알이가 출현하기 전후의 과정을 포함 해서 관찰 기간을 0-20개월로 확대해서 세밀하게 발달 과정을 추 적해 나가야 할 것이다.

\section{REFERENCES}

Chapman, K. L., Hardin-Jones, M., Schulte, J., \& Halter, K. A. (2001). Vocal development of 9-month-old babies with cleft palate. Journal of Speech, Language, and Hearing Research, 44(6), 1268-1283. 
Delgado, R. E., Buder, E. H., \& Oller, D. K. (2010). Action analysis coding and training (AACT). Miami, FL: Intelligent Hearing Systems.

Ha, S., \& Oller, D. K. (2019). Canonical babbling in Korean-acquiring infants at 4-9 months of age. Communication Sciences \& Disorders, 24(1), 1-8.

Ha, S., Seol, A., \& Pae, S. (2014). Vocal development of typically developing infants. Phonetics and Speech Sciences, 6(4), 161-169.

Lee, C. C., Jhang, Y., Relyea, G., Chen, L. M., \& Oller, D. K. (2018). Babbling development as seen in canonical babbling ratios: a naturalistic evaluation of all-day recordings. Infant Behavior and Development, 50, 140-153.

Lewedag, V. L. (1995). Patterns of onset of canonical babbling among typically developing infants (Doctoral dissertation). University of Miami, FL.

Lynch, M. P., Oller, D. K., Steffens, M. L., \& Levine, S. L. (1995). Onset of speech- like vocalizations in infants with Down syndrome. American Journal on Mental Retardation, 100(1), 68-86.

Nathani, S., Ertmer, D. J., \& Stark, R. E. (2006). Assessing vocal development in infants and toddlers. Clinical Linguistics \& Phonetics, 20(5), 351-369.

Oller, D. K. (2000). The emergence of the speech capacity. Mahwah, NJ: Lawrence Erlbaum Associates.

Oller, D. K., \& Eilers, R. E. (1988). The role of audition in infant babbling. Child Development, 59(2), 441-449.

Oller, D. K., Eilers, R. E., Steffens, M. L., Lynch, M. P., \& Urbano, R. (1994). Speech-like vocalizations in infancy: an evaluation of potential risk factors. Journal of Child Language, 21(1), 33-58. 


\section{국문초록}

\section{4-6개월과 7-9개월 영아의 발성 발달}

장현성 $\cdot$ 하승희 ${ }^{2}$

'한림대학교 대학원 언어병리청각학과, ${ }^{2}$ 한림대학교 언어청각학부, 한림청각언어연구센터

배경 및 목적: 음절성 옹알이 산출은 이후 말 발달에 있어서 중요한 지표이다. 본 연구는 4-6개월과 7-9개월의 발성 자료를 종단 수집하 여 발성유형별 변화를 살펴보고, 7-9개월의 음절성 옹알이와 4-6개월의 원시발성과 관계가 있는지 살펴보고자 하였다. 방법: 일반영아 15 명을 대상으로 생후 4-6개월과 7-9개월에 LENA (Language ENvironment Analysis system)를 사용하여 자연스러운 상황에서 영아 의 하루 동안의 발성자료를 수집하였다. 수집된 발성자료 중 아동 당 발성이 가장 많았던 100 분의 자료를 분석하였다. 분석자는 녹음된 자료를 실시간으로 들으면서 각 발화를 6가지 발성형태로 분류하였다. 4-6개월과 7-9개월의 발성형태별 산출빈도를 비교하였으며, 7-9 개월에 음절성 옹알이 단계에 진입한 아동과 그렇지 않은 아동으로 나눈 후 4-6개월의 포먼트 전이를 동반한 발성 빈도를 살펴보고 7-9 개월에 산출한 음절성 옹알이 비율과 상관이 있는지 살펴보았다. 결과: 7-9개월에서 음절성 옹알이가 유의미하게 산출이 증가하였다. 음절성 옹알이 단계에 진입한 아동과 진입하지 못한 아동의 4-6개월의 포먼트 전이를 동반한 발성 빈도 차이가 나타나지 않았으며, 음 절성 옹알이 비율과 4-6개월 포먼트 전이 유무에 따른 발성형태별 산출빈도는 유의미한 상관이 나타나지 않았다. 논의 및 결론: 본 연 구는 음절성 옹알이 단계 전과 후의 다양한 원시발성의 변화를 살펴보았으며, 음절성 옹알이의 시작이 다소 갑작스럽게 일어나는 경향 을 보여주고 있다.

핵심어: 음절성 옹알이, 원시 발성, 포먼트 전이, 한국 영아

본 논문은 한국연구재단 글로벌연구네트워크사업(No. NRF-2016S1A2A2911363)에 의해 수행되었음.

\section{참고문헌}

하승희, 설아영, 배소영(2014). 일반 영유아의 초기 발성 발달 연구. 말소리와음성과학, 6(4), 161-169.

\section{ORCID}

장현성(https://orcid.org/0000-0001-5576-2895); 하승희(https://orcid.org/0000-0003-2133-3720) 